\title{
COFFEE TO GO MARKETING MIX (7P) ANALYSIS TO IMPROVE CUSTOMER SATISFACTION (CASE STUDY KATUHU COFFEE)
}

\author{
Muhammad Fauzan Abdurrahman ${ }^{*}$, Arief Daryanto**), Ani Nuraisyah ${ }^{*}{ }^{* 1}$ \\ ${ }^{*}$ School of Business, IPB University \\ Jl. Raya Pajajaran, Bogor 16151, Indonesia \\ ${ }^{*}$ Department of Economics, Faculty of Economics and Management, IPB University \\ Jl. Agatis, IPB Dramaga Campus Bogor 16680, Indonesia
}

\begin{abstract}
In the 4.0 era, coffee consumption during the 2016-2021 period is predicted to grow an average of 8.22 percent per year. Coffee milk is the best-selling product in the industry. Meanwhile, the development of technology and online transportation allows consumers to order food and beverages from home. This brings the concept of a new coffee shop business model; it is called Coffee to Go. There are so many Coffee to Go in Bogor City, which makes the industry more competitive. This study aims to know Katuhu Coffee's consumer target's characteristics and consumer behavior, customer satisfaction index of Katuhu, importance and performance index of Katuhu Coffee's marketing mix, and formulate marketing strategies for Katuhu Coffee. This research uses the importance-performance analysis (IPA) and customer satisfaction index (CSI) method. The CSI of Katuhu Coffee is 77.2 percent with menu variants, convenient place, doing endorsement, and doing promos in online stores are the attributes need to be fixed. The resulting strategy based on priority includes (1) Innovative menus and product size for coffee and non-coffee menus; (2) Increasing online store promos; (3) Increasing doing endorsement and Instagram ads; (4) Increasing convenience in offline store services; and (5) Expanding Katuhu Coffee sales channel.
\end{abstract}

Keywords: coffee in era 4.0, coffee to go, coffee milk, consumer satisfaction, CSI, IPA

\begin{abstract}
Abstrak: Di era 4.0 kebutuhan kopi selama 2016-2021 diprediksi naik rata-rata 8,22 persen per tahun. Kopi susu adalah produk paling laris di industri. Sementara itu, perkembangan teknologi dan transportasi online membuat pelanggan dapat memesan makanan dan minuman dari rumah. Hal ini melahirkan konsep kedai kopi baru yaitu Coffee To Go. Coffee To Go di Kota Bogor sudah banyak, dimana membuat persaingan industry semakin ketat. Penelitian ini bertujuan untuk mengetahui karakteristik perilaku konsumen Kopi Katuhu, tingkat kepentingan dan kinerja bauran pemasaran Kopi Katuhu, serta memformulasikan strategi pemasaran bagi Kopi Katuhu. Penelitian ini menggunakan metode Importance Performance Analysis (IPA) dan Customer Satisfaction Index (CSI). Nilai CSI Kopi Katuhu sebesar 77,2 persen dengan varian menu, tempat nyaman, endorsement, dan promosi online adalah atributatribut yang harus ditingkatkan kinerjanya. Hasil dari strategi pemasaran untuk Kopi Katuhu sesuai prioritas, yaitu (1) Inovasi menu dan ukuran liter untuk produk kopi dan non-kopi; (2) meningkatkan promo online; (3) meningkatkan endorsement dan iklan instagram; (4) meningkatkan kenyamanan tempat; dan (5) memperluas channel pemasaran Kopi Katuhu.
\end{abstract}

Kata kunci: kopi di era 4.0, coffee to go, kopi susu, kepuasan konsumen, CSI, IPA

\footnotetext{
${ }^{1}$ Corresponding author:

Email: anynuraisyah@apps.ipb.ac.id
} 


\section{INTRODUCTION}

During the 2016-2021 period, Indonesian coffee consumption is predicted to grow an average of $8.22 \% /$ year. In 2021, the coffee supply is predicted to reach 795 thousand tons with a consumption of 370 thousand tons, resulting in a surplus of 425 thousand tons (Santirianingrum, 2019). The increase in the amount of coffee consumption and lifestyle changes in Indonesia have an impact on the Indonesian coffee industry. Indonesia's coffee industry has increased in the downstream industry, as seen in the rise of coffee shops. Many coffee products are often found in coffee shops, such as black coffee, modern milk coffee, roasted coffee beans, and sachet coffee. One of the products produced by coffee that is currently selling among the public and has become one of the contributors to the increase in coffee consumption is the latest milk coffee. Modern milk coffee is a coffee drink that has been mixed with additional ingredients, such as milk, palm sugar, syrup, and others, to produce a diverse coffee flavor. As reported from a survey conducted by IDN Times, out of 386 respondents in six major cities in Indonesia, the majority of today's milk coffee connoisseurs consume milk coffee today on average in less than three times a month (41.7\%), with private workers ranked top with a percentage of $47.6 \%$ and students with a percentage of $35.5 \%$ (Cahya, 2019).

Meanwhile, the development of technology and online transportation becomes a container that can be used by coffee shops in connecting consumers (Alfirahmi, 2019). The trend of milk coffee giving rise to many brands of milk coffee shops such as Kulo Coffee, Janji Jiwa, Kopi Kenangan, Kopi Soe, and Jokopi are the five most popular according to Indonesian people (Cahya, 2019). Of the five coffee shops mentioned before, they all have the same characteristic that their coffee shop model is Coffee to Go. Coffee to Go is the most significant contributor to the sales of dairy coffee products, especially milk coffee in Indonesia. Coffee to Go generally does not have a spacious building and only provides a few benches. This concept is perfect for consumers who want to drink coffee but can't come or linger on the spot (Supriyatna, 2019). The city of Bogor itself has been mushroomed by Coffee to Go, and both came from franchisees or independents. This shows the competition of Coffee to Go industry and milk coffee is getting tighter. One of the Coffee to Go affected by the intense competition is Katuhu Coffee.

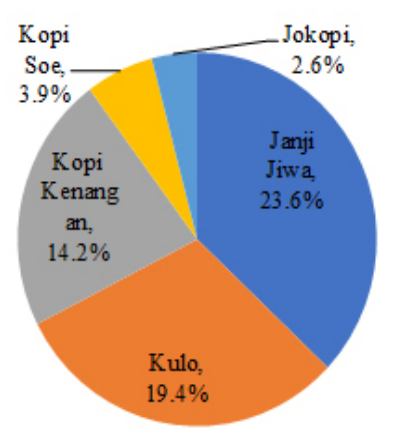

Figure 1. The most remembered Coffee to Go brand by the Indonesian people (Cahya, 2019)

Katuhu Coffee is an independent Coffee to Go established in August 2019. Founded on the grounds that the owner sees opportunities for business models and market needs for dairy coffee products are on the rise in the city of Bogor. Meanwhile, Coffee to Go around Katuhu Coffee is quite a lot, such as Lana Coffee, Kopi Depan Rumah, Kopi Soe, Kopi Janji Jiwa, Kopi Kulo, etcentra. The stronger competition of Coffee to Go in Bogor makes Katuhu Coffee's income tends to decrease per month. Katuhu Coffee's income in the early months reached Rp50.000.000,00 with averages more than 100 sales per day, but in the fourth month onwards only reached around Rp35.000.000,00 with averages around 80 sales per day. Things got worse as the covid-19 pandemic progressed. Katuhu Coffee sales in March 2020 are only about 50-60 glasses per day. One of the main problems that need to be fixed and reviewed, primarily related to the strategy and performance of marketing attributes that Kopi Katuhu has implemented.

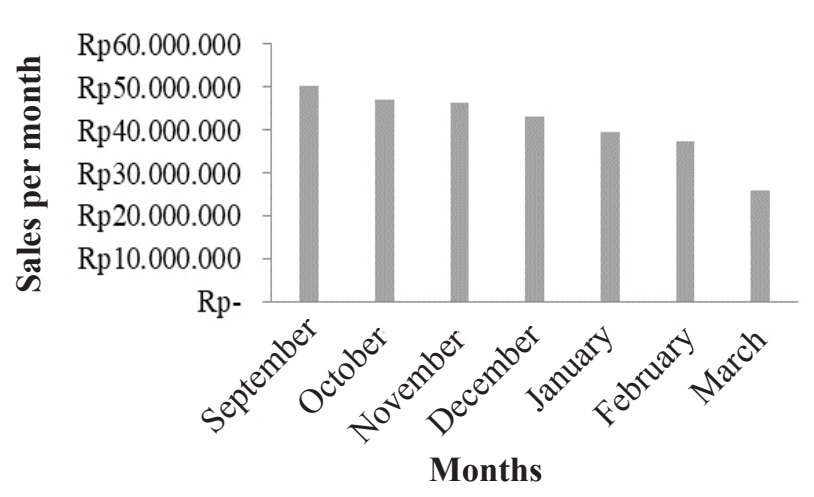

Figure 2. Katuhu Coffee sales on Sept 19 - Mar 20 
As a Coffee to Go business that is currently growing, Katuhu Coffee needs to know its target consumers' characteristics in their purchasing decisions towards Coffee to Go products. According to Ranitaswari's (2018) research entitled Analysis of Consumer Satisfaction on Coffee Product Quality and Service Quality Using the Importance Performance Analysis Method (Case Study at Geo Coffee), the use of the Importance Performance Analysis and Customer Satisfaction Index methods aims to obtain results of consumer satisfaction, and the level of importance and performance of the marketing mix became the basis for designing a marketing strategy for Geo Coffee to increase their customer satisfaction which impact can improve Geo Coffee sales. According to Yola's (2013) research entitled Analysis of Consumers Satisfaction on Quality Service and Product Prices at Supermarket Using the Method of Importance Performance Analysis (IPA), the use of the Importance Performance Analysis method obtained various attributes that are included in the priority of improvement to keep customers loyal to shopping at their company. Katuhu Coffee also needs to evaluate the performance and importance of the marketing mix that has been implemented by Kopi Katuhu to know the implementation of The Katuhu Coffee marketing mix, which is included in the priority of improvement to improve its consumer satisfaction which indications can increase sales for Katuhu Coffee. Besides, this also needs to be done for Katuhu Coffee to survive and compete in the market.

This research was conducted by analyzing consumer satisfaction obtained from assessing the level of importance and performance of the 7P marketing mix attributes that Kopi Katuhu has implemented. The characteristics of Katuhu Coffee's target consumers were analyzed using descriptive analysis. The level of consumer satisfaction was analyzed using the Customer Satisfaction Index (CSI), namely by weighting the level of importance and level of performance on the attributes of physical products and services of Kopi Katuhu according to Kopi Katuhu consumers. In improving attributes, in this study, a mapping of consumer perceptions of the importance and performance level of the physical attributes and services of Kopi Katuhu was carried out through Importance Performance Analysis (IPA). Then a comparative study was conducted with other Coffee to Go shops on business conditions and the application of the marketing mix between Coffee to Go around the Kopi Katuhu area as well as examining non-consumer responses to the interests of the Katuhu Coffee marketing mix as a Coffee to Go to get customer insight of potential customers about respondents' expectations. Against a Coffee to Go. Based on the background and formulating the Katuhu Coffee Problem, this research aims to:

1. Identify the characteristics and behavior of targeted consumers of Katuhu Coffee.

2. Know the level of consumer satisfaction of Katuhu Coffee.

3. Formulate a strategic design to increase customer satisfaction for Kopi Katuhu.

\section{METHODS}

This research was conducted at Kopi Katuhu, located at Jalan Lodaya 1, No.6, Bogor. This study's data collection and processing time was conducted for one month, from June to July 2020. The data used in this study consists of primary and secondary data. Primary data consists of an overview obtained from an in-depth interview. Profile and characters of Coffee to Go consumers obtained from questionnaires. The level of importance and performance of Katuhu Coffee marketing mix was obtained from questionnaires filled out by consumers of Katuhu Coffee. The comparative study was obtained from an in-depth interview. Non-consumers responses to the importance of Katuhu Coffee marketing mix were obtained from an in-depth interview. Secondary data consists of numbers of Coffee shops in Bogor City, competitors, and supporting data obtained from the internet and previous studies. Data collection is done by conducting interviews, questionnaires, and library studies. The sampling technique uses a nonprobability sampling technique with the purposive sampling method.

Katuhu Coffee is an independent Coffee to Go established in August 2019. Although it has been running for almost a year, Katuhu Coffee revenue often decreases every month. Katuhu Coffee revenue in the fourth month onwards only reached around Rp35.000.000,00. Things got worse as the covid19 pandemic progressed. As a Coffee to Go business that is currently growing, Katuhu Coffee also needs to evaluate the performance and importance of the marketing mix that has been implemented by Kopi Katuhu to know the implementation of The Katuhu Coffee marketing mix, which is included in the priority 
of improvement, to improve its consumer satisfaction which indications can increase sales for Katuhu Coffee. Besides, this also needs to be done for Katuhu Coffee to survive and compete in the market.

This study was conducted in Kopi Katuhu by identifying the customer characteristics and behavior of targeted consumers of Katuhu Coffee and analyzing Katuhu Coffee customer satisfaction value obtained from the assessment of the level of interest and performance attributes of the 7P marketing mix that Katuhu Coffee has implemented. After that, the study conducted comparative studies and reviewed non-consumer responses to the importance of a Coffee to Go marketing mix to obtain potential customer insights. Customer satisfaction index (CSI) is used to determine customer satisfaction levels with an approach that considers the level of importance of the attributes measured (Saputra, 2017). Consumer satisfaction assessment is conducted to find out how Katuhu Coffee performance level towards all assets that Katuhu Coffee has done and fulfill the needs of their consumers. Importance Performance Analysis (IPA) is used to compare how consumers can felt performance compared to the desired level of satisfaction (Martilla and James, 1977). This technique helps to understand customer satisfaction better and prioritize a product or service that needs improvement. The results are used in implementing the appropriate strategic design to increase sales and customer satisfaction for Katuhu Coffee. Descriptive analysis is used to identify the application 7P marketing mix of Katuhu Coffee, characteristics, and behavior of Katuhu Coffee target customers.

\section{RESULTS}

\section{Characteristics and Behavior of Targeted Consumers of Katuhu Coffee}

Consumer characteristics are a number of characteristics or characteristics of consumers visiting and purchasing the products (Afriyanti, 2018). Based on the results of the study, the majority of Katuhu Coffee consumers are Male (55.3\%) 18-22 years old (40.4\%) who are students or students $(45.7 \%)$. The majority of consumers have made a purchase transaction 5-6 times (35.1\%). Most consumers know Katuhu Coffee from the food delivery app (93.6\%) and social media (74.5\%). At the purchasing decision stage, the target consumer of Katuhu Coffee chose drinks for intermezzo as the main reason for making the purchase $(73 \%)$, with sugar palm milk coffee is the top choice of most commonly purchased (91\%). The majority of respondents agreed to change in coffee-to-go product purchase decisions during the covid-19 pandemic (56\%) by selecting a reduction in purchase intensity $(64 \%)$ to save on expenses $(80 \%)$. The majority of respondents knew of a Coffee to Go information from social media (91\%). The majority of respondents most often spend a budget of Rp15.000,00-Rp19.000,00 for each purchase of Coffee to Go products (59\%). The top three attributes considered in the purchase of Coffee to Go products include (1) Coffee menu variants (83\%); Product flavors (81\%), and (3) Non-coffee menu variants (75\%). In addition to these attributes, in pandemic conditions, several attributes are of additional consideration, such as (1) Family promo (62\%); and (2) Liter products (41\%). Frequency of purchase 3-4 times a month (37\%) with daylight $(46 \%)$ is the most frequently selected time. All respondents were satisfied after purchasing Coffee to Go products (100\%).

\section{Consumer Satisfaction Level}

The level of customer satisfaction needs to be known by Katuhu Coffee to evaluate how consumers are satisfied with the products and services offered. The level of customer satisfaction can be measured using the Customer Satisfaction Index (CSI) method. Customer Satisfaction Index (CSI) is used to determine the overall level of visitor satisfaction by looking at the level of importance of product/service attributes (Syukri, 2014). Calculation using the Customer Satisfaction Index (CSI) method requires an average score of importance and an average score for the performance level of each attribute of Katuhu Coffee. According to Paojiyah (2018), the analysis of the attributes contained in the Customer Satisfaction Index (CSI) will show whether these attributes determine significantly and make a considerable contribution to company revenue so that they can be used for planning control tools and as a basis for work evaluation. End so that company performance errors can be corrected. The Customer Satisfaction Index (CSI) value is obtained from the quotient between the Total Weight Score and the maximum scale of the Likert scale, namely a scale of 5 , then multiplied by $100 \%$. Each attribute is given a differentiating code based on its marketing mix variables, namely P1 for the product, $\mathrm{P} 2$ for the place, $\mathrm{P} 3$ for the price, $\mathrm{P} 4$ for promotion, $\mathrm{P} 5$ for people, $\mathrm{P} 6$ for the process, and $\mathrm{P} 7$ for physical evidence. Calculation of the Customer 
Satisfaction Index (CSI) of Katuhu Coffee according to 94 respondents of Katuhu Coffee consumers is $77.2 \%$. This indicates that most consumers are satisfied with the performance of Katuhu Coffee products and services. The result can be seen in Table 1 .

\section{Importance Performance Analysis}

Importance Performance Analysis (IPA) is a tool aid in analyzing or comparing the extent to which the performance/service perceived by service users is compared to the desired level of satisfaction (Yola, 2013). Importance Performance Analysis (IPA) consists of a pair of coordinate axes where the Y-axis is of interest, and the $\mathrm{X}$-axis is the performance of various elements (Martilla and James, 1977). Each quadrant combines the level of importance and performance provided by the service element's customer or user. Attributes that are included in the priority of improvement are the attributes that belong to quadrant II. More details can be seen in Figure 3.

Table 1. Calculation of Katuhu Coffee customer satisfaction index

\begin{tabular}{|c|c|c|c|c|c|}
\hline \multirow[b]{2}{*}{ Code } & \multirow[b]{2}{*}{ Attribute } & \multicolumn{2}{|c|}{ Importance Level } & \multicolumn{2}{|c|}{ Performance level } \\
\hline & & MIS & $\begin{array}{l}\text { Weighted } \\
\text { factors }\end{array}$ & MPS & $\begin{array}{c}\text { Weighted } \\
\text { score }\end{array}$ \\
\hline P1.1 & Taste & 4.67 & 3.76 & 4.18 & 0.16 \\
\hline $\mathrm{P} 1.2$ & Menu variants & 4.40 & 3.54 & 3.29 & 0.12 \\
\hline $\mathrm{P} 1.3$ & The brand logo is clear to read & 4.21 & 3.39 & 4.07 & 0.14 \\
\hline P1.4 & Brands are accessible for consumers to remember & 4.23 & 3.41 & 4.13 & 0.14 \\
\hline P1.5 & Brands are engaging both verbally and visually & 4.01 & 3.23 & 3.64 & 0.12 \\
\hline P1.6 & Attractive packaging & 4.16 & 3.35 & 4.02 & 0.13 \\
\hline P2.1 & The location is easy to see clearly & 4.36 & 3.51 & 4.62 & 0.16 \\
\hline P2.2 & The location is on the side of the road & 4.22 & 3.40 & 4.20 & 0.14 \\
\hline P2.3 & The location is easily accessible & 4.17 & 3.36 & 4.32 & 0.15 \\
\hline P2.4 & The location has a comfortable place & 4.15 & 3.34 & 2.56 & 0.09 \\
\hline P2.5 & The location is in a busy area & 4.19 & 3.37 & 4.28 & 0.14 \\
\hline P3.1 & Price compatibility with product quality & 4.45 & 3.58 & 4.07 & 0.15 \\
\hline P3.2 & Competitive prices with other brands & 4.28 & 3.44 & 4.27 & 0.15 \\
\hline P4.1 & Endorsement via Instagram & 4.41 & 3.55 & 3.03 & 0.11 \\
\hline P4.2 & Build relationships with consumers & 4.15 & 3.34 & 3.98 & 0.13 \\
\hline P4.3 & Nameplate clarity & 4.28 & 3.44 & 4.05 & 0.14 \\
\hline P4.4 & Register your name and location on google my business & 4.16 & 3.35 & 4.32 & 0.14 \\
\hline P4.5 & Active social media & 4.54 & 3.66 & 4.04 & 0.15 \\
\hline P4.6 & Register your name and location at pergikuliner.com & 3.18 & 2.56 & 3.70 & 0.09 \\
\hline P4.7 & Procurement of promos in offline stores & 3.19 & 2.57 & 2.44 & 0.06 \\
\hline P4.8 & Procurement of promos in online stores (Go-food and Grab food) & 4.31 & 3.47 & 2.98 & 0.10 \\
\hline P4.9 & Participate in events & 3.49 & 2.81 & 3.24 & 0.09 \\
\hline P5.1 & Servant alertness & 4.17 & 3.36 & 4.04 & 0.14 \\
\hline P5.2 & Hospitality of waiters & 3.84 & 3.09 & 4.12 & 0.13 \\
\hline P6.1 & Serving speed & 4.28 & 3.44 & 4.14 & 0.14 \\
\hline P6.2 & Transaction speed & 4.21 & 3.39 & 4.17 & 0.14 \\
\hline P6.3 & Procurement of e-wallet payments & 4.15 & 3.34 & 3.97 & 0.13 \\
\hline P7.1 & Spotlighting & 4.23 & 3.41 & 3.93 & 0.13 \\
\hline P7.2 & Decoration of the place & 4.01 & 3.23 & 3.43 & 0.11 \\
\hline P7.3 & Operational hour & 4.16 & 3.35 & 4.07 & 0.14 \\
\hline & Total & 124.28 & 100 & 115.30 & 3.86 \\
\hline & Customer satisfaction index $(\%)$ & & & & 77.2 \\
\hline
\end{tabular}




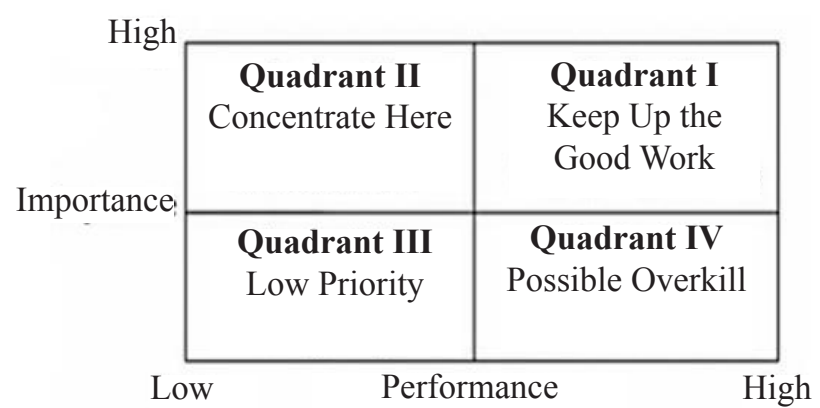

Figure 3. Importance performance analysis diagram (Martilla and James, 1977)

Prioritized attributes for performance improvement are attributes that have below-average performance levels and above-average importance levels or attributes that fit into quadrant II of IPA cartesian charts. Attributes that went to quadrant II need to focus on improvements because these attributes indicate the weakness of Katuhu Coffee marketing mix performance, but the importance of these attributes is so high according to consumers' assessment. These attributes include (1) menu variants; (2) the location has a convenient place (convenience); (3) endorsement; and (4) procurement of promo in the online store. The results of the IPA diagram mapping can be seen in Figure 4.

The study results compared the study with two other independents Coffee to Go outlets, such as Lana Coffee and Depan Rumah Coffee. Lana Coffee has increased sales during the COVID-19 pandemic endorsements, and Instagram ads for Lana Coffee are far more frequent. Compared to the other two coffee shops, the Lana Coffee market's reach is outside Bogor City. In terms of products, only Katuhu Coffee does not sell products in large size. In terms of places, only Katuhu Coffee does not provide seating for consumers. In terms of promotions, Katuhu Coffee does fewer promotions in Go food and Grab food than Depan Rumah Coffee and Lana Coffee.

Based on the assessment of non-consumer respondents of Katuhu Coffee towards the level of importance of Katuhu Coffee marketing mix as a Coffee to Go, nonconsumer respondents have an equal perception of the assessment with the respondents of consumers Katuhu Coffee. It is just that there are differences in the attributes of the location, having a comfortable, clean place, and providing some bench seating. This attribute's interest score is below average is indicated that most non-consumers more often order Coffee to Go products online.

\section{Segmentation, Targeting, Positioning Consumers of Katuhu Coffee}

Market segmentation is carried out to see which markets can be targeted to increase the number of visits (Rismawati, 2019). Segmentation is carried out based on geographic, personal, and psychographics (Mulyana, 2019). In the geographic segment, Kopi Katuhu does not focus its purchases in the Lodaya area only, but on Bogor City as a whole because sales are also made through online shops with food delivery applications (Go food and Grab food). In the private segment, Kopi Katuhu measures its market to people aged 20-40 who are students and workers. All were chosen because Katuhu Coffee is close to the IPB University diploma campus and the PT in the city center. Telkom Indonesia. Kopi Katuhu prioritizes the contemporary coffee milk consumers in the psychographic segment but cannot visit the coffee shop or linger at the coffee shop due to time constraints.

The next step after segmentation is checking and selecting the target market. The strategy taken by Katuhu Coffee in deciding the target market is to pay attention to the size or number of segments that have been selected. The target market's market segments are students and workers because they have the highest level of potential for purchasing new milk coffee products. Katuhu coffee assessments students and workers need to drink coffee, either because that category likes to drink coffee or that category most often requires a drink to accompany their activities.

After segmenting the market and determining the target market, the company needs to determine its offering position. Positioning is an action to build the image and value offered so that customers understand and appreciate its position in running it with competitors (Mulyana, 2019). In doing positioning, Katuhu Coffee uses several variables, including:

\section{Brand Attributes}

The brand attribute is instilled in consumers through the brand slogan of Katuhu Coffee, namely Sahabat katuhu. Every purchase of Katuhu Coffee product uploaded on Instagram social media by consumers, Katuhu Coffee always re-uploads its social media accounts. It puts the spotlight on friends on Kopi Katuhu's Instagram account. Katuhu Coffee applies this method to maintain good relationships and build loyalty with consumers. 


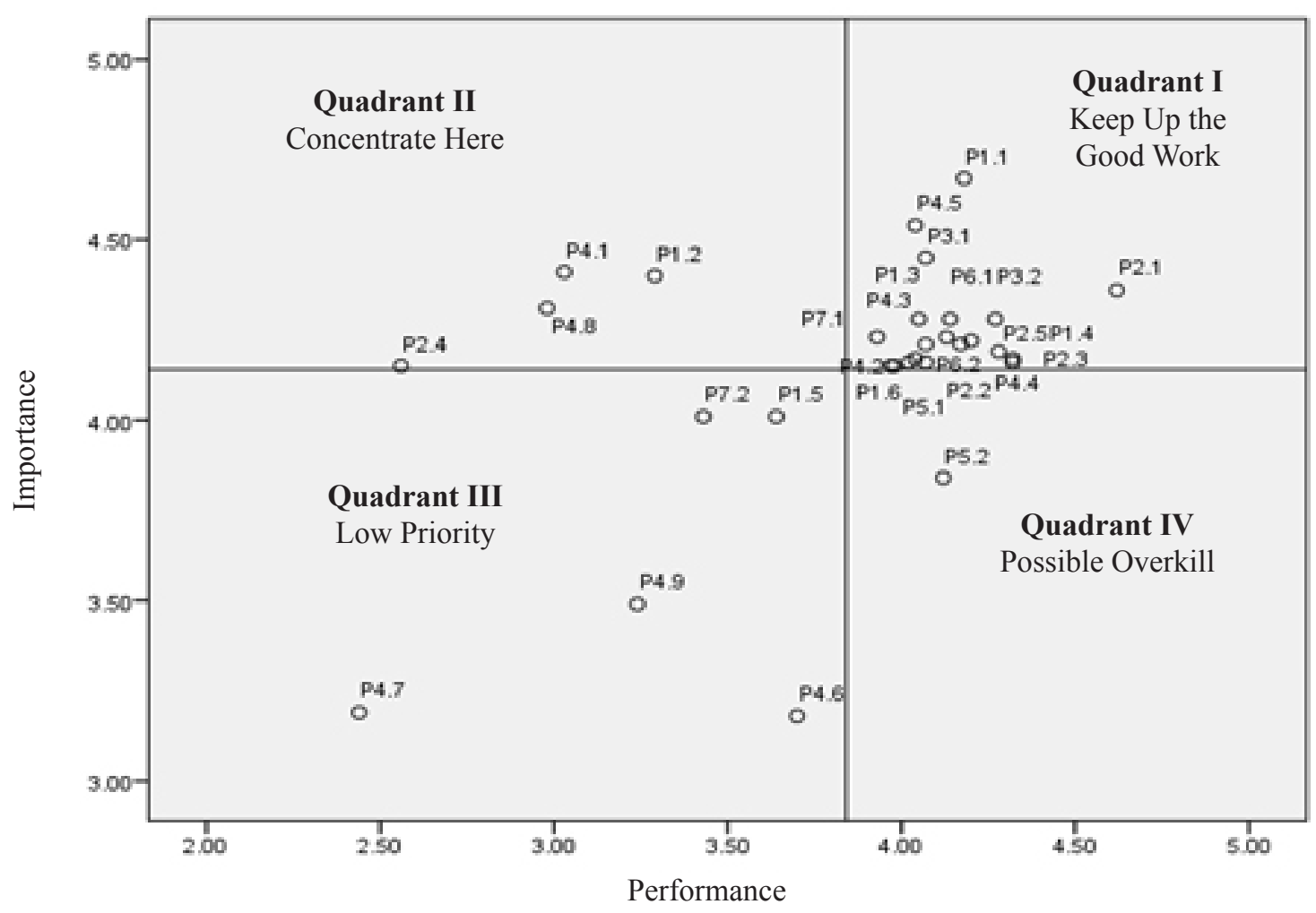

Figure 4. Katuhu Coffee IPA Diagram

\section{Price and Quality}

The price offered by Katuhu Coffee is around $\mathrm{Rp}$. 15,000 - Rp. 23,000. The price offered is competitive in the market and can be achieved by students and workers. Apart from its affordable price, Katuhu Coffee also carries out quality standards for all the products it sells. The coffee beans used by Katuhu Coffee use coffee beans from West Sumatra, so the resulting taste has a distinctive orange and caramel flavor. For other ingredients such as syrup and powder, Katuhu Coffee never changes suppliers so that the resulting taste is always consistent.

\section{Competitors}

The proliferation of modern coffee milk shops with the Coffee to Go model in Bogor City has resulted in intense competition. Katuhu Coffee pays attention to product taste and prices to compete with other Coffee to Go brands' products to compete with explorers. Katuhu coffee is focused on taste, especially in palm sugar milk coffee. Besides, Kopi Katuhu always re-uploads Katuhu Coffee product posts uploaded by consumers to social media and puts the spotlight on friends of Katuhu's Instagram coffee accounts to create consumer loyalty.

\section{Priority to Improve the Performance Attribute Marketing Mix of Katuhu Coffee}

Achievementofgoals in increasing customer satisfaction Katuhu coffee, it is necessary to improve the marketing mix attribute's performance based on consumer assessments. Evaluation from consumers is needed to determine consumer responses to the Katuhu Coffee marketing mix attributes' importance and performance. It is used to consider strategy formulation to increase customer satisfaction, thus impacting on repeat purchases or recommending Katuhu Coffee to others. At this stage, all attributes assessed by consumers will be mapped in a Cartesian chart importance-performance analysis based on calculating the level of importance and the level of performance of the Katuhu Coffee marketing mix. Attributes prioritized for performance improvement are attributes with a performance level below average and whose importance is above average or attributes included in quadrant II of the IPA Cartesian diagram.

\section{Quadrant I (Keep Up The Good Work)}

The attributes included in this quadrant have an aboveaverage performance level and an above-average importance level. Twenty attributes have an average performance level above 3.84 and the average value 
of the level of importance above 4.14. These attributes consist of: taste, transparent legible brand logo, easy to remember the brand for consumers, attractive packaging, good visibility, easy access, curbside appeal, the location being in a busy area (walk-in traffic), price agreement with product quality, competitive prices with other brands, establishing relationships with consumers, clarity of signboards, registering locations and names to Google my Business, active social media, waiter alertness, serving speed, transaction speed, procurement of e-wallet payments, place lighting, and operating hours because although Katuhu Coffee's performance is not yet perfect, consumers think that most of the Katuhu Coffee attribute performance is above the average consumer. Based on the results of the IPA diagram mapping, consumers assess that the majority of the performance of the price and process attributes are very good, as evidenced by all the attributes in this category that fall into this quadrant because the selling price and service process of Katuhu Coffee are following consumer expectations. The IPA diagram's mapping results show that quadrant I has the highest number of attributes, namely the twenty attributes. Therefore, Katuhu coffee needs to maintain the attributes included in this quadrant because these attributes are an advantage.

\section{Quadrant II (Concentrate Here)}

The attribute included in this quadrant means that it has an average value of performance level below 3.84, and an average value level of its importance level is above 4.14. Because it indicates that the attributes included in quadrant II are a priority for improvement because they are weaknesses. Some of the attributes that fall into quadrant II include menu variants, convenience location, endorsement via Instagram, and promos' procurement at online stores. To improve performance, Katuhu Coffee needs to focus on performance improvements on these four attributes. When viewed from the mapping of the IPA diagram, it can be concluded that the menu variants that Katuhu coffee has are considered low by consumers. Therefore, Kopi Katuhu can substitute some unsatisfactory menus or add several new menu variants, diversify palm sugar coffee products, and innovate literary products. Based on the questionnaire results, the majority of Katuhu Coffee target consumers choose palm sugar milk coffee as the most frequently purchased product, choosing the coffee and non-coffee menu variant categories as the choice category that falls into the top three attribute choices. Those are considered in making purchases and literary products as an additional consideration during the Covid 19 pandemic.

Besides, having a comfortable, clean place and providing a bench are included in this quadrant. Because this is indicated because Katuhu coffee does not have a dine-in bench and has a pretty lousy cleanliness area, as evidenced by the trash can next to the shop; therefore, Katuhu coffee can clean up the shop environment and add a few more dine-ins. The other two attributes come from the promotional attribute group: endorsement through Instagram and procuring promos at online stores (Go food and Grab food). Because of promos' procurement at the online store, Katuhu Coffee has only procured two Go food promos. Katuhu Coffee can improve its promotional performance by participating in more frequent Go food and Grab food promos. If Katuhu Coffee registers promos on Go food or Grab food, the opportunity for Katuhu Coffee to appear on the Go food or Grab food recommendation pages is getting bigger. Another attribute that goes into this quadrant is endorsement via Instagram. In addition to the performance of doing endorsements through Instagram, which was considered unacceptable, most Katuhu Coffee target consumers know the development of a Coffee to Go from social media. This was in line with the statement that the user-based social media in Indonesia is relatively well-off and active. According to We Are Social, $32 \%$ of social media users have Instagram accounts, $74 \%$ of mobile users installed social media apps on their phones, and 57\% made an online purchase (Tradegecko, 2015). 62.3\% of Instagram users in Indonesia have been active users for 1 to 3 years. $74.9 \%$ of these users have made purchases from social commerce accounts on Instagram (Dinna and Zhu, 2016).

\section{Quadrant III (Low Priority)}

Atibut, which is included in this quadrant, has an average performance level below 3.84 and an average level of importance below 4.14. The attributes included in this quadrant have a performance level value below the majority of consumers' expectations. Still, the importance level of these attributes is considered not very important, according to most consumers. There are five attributes in this quadrant, including attractive brands both visually and verbally, registering names and locations to Pergikuliner.com, procuring promotions at offline stores, participating in events, and decorating 
places. The attributes included in this quadrant can be used as material for evaluating the performance of Katuhu Coffee, which can be improved later.

\section{Quadrant IV (Possible Overkill)}

The attributes included in this quadrant have an average level of performance above 3.84 , but the average value of their importance is below 4.14. The attributes included in this quadrant have a performance level value above the average of most consumers. Still, according to most consumers, the importance level of these attributes is considered not very important. There is one attribute that falls into this quadrant, namely the friendliness of the servants. This indicates that the majority of consumers are not too concerned with waiter friendliness.

\section{Managerial Implications}

Based on the results ofidentification of the characteristics of target consumers of Katuhu Coffee to the decision to purchase Coffee to Go products, mapping diagrams IPA Coffee Katuhu, comparative study analysis with other Coffee to Go, as well as the response of non-consumer respondents to the level of interest of the marketing mix Katuhu Coffee as Coffee to Go, produced several strategic recommendations for Katuhu Coffee based on priority, (1) Innovative menus and product size for coffee and non-coffee menus; (2) Increasing online store promos; (3) Increasing doing endorsement and Instagram ads; (4) Increasing convenience in offline store services; and (5) Expanding Katuhu Coffee sales channel.

\section{CONCLUSIONS AND RECOMMENDATIONS}

\section{Conclusions}

Based on the study results, the targeted consumer of Katuhu Coffee chose drinks for intermezzo as the main reason for making the purchase, with sugar palm milk coffee being the top choice of most commonly purchased. The majority of respondents agreed to change in coffee to go product purchase decisions during the covid-19 pandemic by selecting a reduction in purchase intensity to save their expenses. The majority of respondents knew of a Coffee to Go information from social media. The majority of respondents most often spend a budget of Rp15.000,00-Rp19.000,00 for each purchase of Coffee to Go products. The top three attributes considered in the purchase of Coffee to Go products include (1) Coffee menu variants; Product flavors, and (3) Non-coffee menu variants. In addition to these attributes, several attributes are of additional consideration in pandemic conditions, such as (1) Family promo; and (2) Liter products. Frequency of purchase 3-4 times a month with daylight is the most frequently selected time. All respondents were satisfied after purchasing Coffee to Go products.

Calculations of the Customer Satisfaction Index (CSI) of Katuhu Coffee is $77.2 \%$. Katuhu Coffee still needs to improve their performances. Attributes that went to quadrant II needs focus of improvements; these attributes are (1) menu variants; (2) The location has a convenient place (convenience); (3) Endorsement; and (4) procurement of promo in the online store. Those attributes need to be repaired immediately.

Based on theresults of identification of the characteristics of target consumers of Katuhu Coffee to the decision to purchase Coffee to Go products, mapping diagrams IPA Coffee Katuhu, comparative study analysis with other Coffee to Go, as well as the response of non-consumer respondents to the level of interest of the marketing mix Katuhu Coffee as Coffee to Go, produced several strategic recommendations for Katuhu Coffee sorted by priority (1) Innovative menus and product size for coffee and non-coffee menus; (2) Increasing online store promos; (3) Increasing doing endorsement and Instagram ads; (4) Increasing convenience in offline store services; and (5) Expanding Katuhu Coffee sales channel.

\section{Recommendations}

There are suggestions that Katuhu Coffee and further research can be made. Katuhu Coffee needs maintenance attributes that have good performances, which can be seen in quadrant I. Katuhu Coffee needs to improve its attributes performances in quadrant II. Katuhu Coffee needs to conduct regular customer satisfaction surveys. Further research is expected to analyze the internal condition of Katuhu Coffee management in more detail. 


\section{REFERENCES}

Afriyanti S, Rasmikayati E. 2018. The best marketing strategy based on consumer behavior in facing competition between coffee shops in Jatinangor. Agroinfo Galuh Student Scientific Journal 4(3):859-872.

Alfirahmi. 2019. Fenomena kopi kekinian di era 4.0 ditinjau dari marketing 4.0 dan Teori Uses dan Effect. Jurnal Lugas 3(1):24-32. https://doi. org/10.31334/ljk.v3i1.410.

Cahya. 2020. Meramal usia kopi susu kekinian: Hanya tren atau panjang umur betulan?. https://www. idntimes.com/food/dining-guide. [5 Jul 2020].

Dinna A, Zhu YQ. 2016. Investigating effectiveness of source credibility elements on social commerce endorsement: The case of instagram in Indonesia. PACIS :232.

Martilla JA, James JC. 1977. Importance performance analysis an easily-applied technique for measuring attribute and performance can further the development of effective marketing programs. Journal of Marketing 41(1):77-79. https://doi.org/10.1177/002224297704100112.

Mulyana M. 2019. Segmentasi pasar, penargetan pasar dan pemosisian. Materi Tutorial Online :23-29. https://doi.org/10.31227/osf.io/tcuj2.

Paojiyah SR. 2018. Analysis of consumer satisfaction and loyalty of Dapoer Meneer Resto and Coffee Shop Serang City [thesis]. Bogor: Sekolah Program Pascasarjana, Institut Pertanian Bogor.

Ranitaswari PA, Mulyani S, Sadyasmara CAB. 2018. Analysis of consumer satisfaction on the quality of coffee products and service quality using the Importance Performance Analysis Method (Case study at Geo Coffee). Journal of Agroindustrial Engineering and Management 6(2):147-157. https://doi.org/10.24843/JRMA.2018.v06.i02. p06.

Rismawati F, Wahyuni S, Widodo J. 2019. Strategi pemasaran STP (Segmenting, Targeting, Positioning) Larissa Aesthetic Center cabang Jember. Jurnal Ilmiah Ilmu Pendidikan, Ilmu Ekonomi dan Ilmu Sosial 13(2):68-72.https:// doi.org/10.19184/jpe.v13i2.10793.

Santirianingrum S, Dharmani IAAN. 2019. The impact of experiential marketing and repurchase intention through customer satisfaction in coffee industry. IJESS: International Journal of Education and Social Science 1(1):37-46.

Saputra. 2017. Analysis of customer satisfaction and loyalty to attributes of meat grinding results (Case study of Sumber Rejeki Group, Seruyan Regency). Journal of Agribusiness 19(2):14124807. https://doi.org/10.31849/agr.v19i2.781.

Supriyatna. 2019. Melirik potensi bisnis Coffee to Go, modalnya mulai dari 5 jutaan. https://www.suara. com/bisnis. [5 Jul 2020].

Syukri SHA. 2014. The application of the Customer Satisfaction Index (CSI) and gap analysis on the quality of Trans Jogja services. Scientific Journal of Industrial Engineering 13(2):103-111.

Tradegecko. 2015. How social media selling is disrupting ecommerce in Indonesia. https:// www.tradegecko.com/blog. [5 Jul 2020].

Yola M, Budianto D. 2018. Analysis of consumer satisfaction on service quality and product prices at supermarkets using the Importance Performance Analysis Method. Journal of Industrial Systems Optimization 12(12):301309. 